\title{
Optimization of hollow blocks production from sawdust waste from Khaya senegalensis (Desr.) A. Juss. and Anogeissus leiocarpus (DC.) Guill. \& Perr., as partial replacement for sand
}

\author{
David Oriabure Ekhuemelo*, Victoria Alfa and Emmanuel Tersugwue Tembe \\ Department of Forest Production and Products, University of Agriculture, Makurdi, Benue State, Nigeria \\ *Corresponding Author: davidekhuemelo@gmail.com
}

\begin{abstract}
This study evaluated the properties of hollow blocks produced from Khaya senegalensis and Anogeissus leiocarpus sawdust as a partial replacement for sand. The study was carried out at Federal University of Agriculture Makurdi (FUAM), Nigeria. Sawdust was collected from Timber Shed in Wurukum, boiled and dried. Mortal was prepared using mixed ratio of 1:6 (cement to sand). River sand was successively replaced with sawdust at various replacement levels of $0,2,4,6$ and 8 percentages, respectively. Block samples produced were subjected to compressive strength, density and water absorption test. Results showed that bulk density of blocks from each sawdust replacement levels decreased with an increase in the percentage of sawdust replacement from 1,111.400 $\mathrm{kg} \mathrm{m}^{-3}$ to $1,329.00 \mathrm{~kg} \mathrm{~m}^{-3}$. Mean water percentage absorption was least $(11.13 \%$ and $11.34 \%)$ in $4 \%$ sawdust replacement level for Anogeissus leiocarpus and $2 \%$ Khaya senegalensis, respectively. The highest compressive strength $\left(3.32 \mathrm{~N} \mathrm{~mm}^{-2}\right.$ and $\left.3.42 \mathrm{~N} \mathrm{~mm}^{-2}\right)$ was recorded for $2 \%$ sawdust replacement level. The best sawdust replacement level in this study was $2 \%$ for both Annogeissus leiocarpus and Khaya senegalensis and is therefore recommended for non-load bearing walls.
\end{abstract}

Keywords: Replacement, Sand, Sawdust, Hollow blocks, Compressive strength.

\section{INTRODUCTION}

Sawdust is an underutilized byproduct of sawmills and timber shed as industrial waste material which contributes to environmental pollution. As the demand for wood and wood products increase, there is a corresponding increase in the volume of sawdust wastes generation (Ogunbode et al., 2013). Dosunmu \& Ajayi (2002) reported that so many problems such as degradation of the urban environment, reduction of the aesthetic value of cities, production of unpleasant putrefying odours during the rains and pollution of air with smoke during burning of sawdust waste. These they reported to also constitute health hazards to humans as the dump sites become breeding places for worms and insects. The Timber Sheds in Makurdi turn out high volume of sawdust every day without corresponding utilization for added value products.

Sandcrete block is a combination of material comprising of Portland cement (binder), sharp sand and water (Sholanke et al., 2015). World over and Nigeria in particular, hollow sandcrete blocks have been in use in and play prominent purpose in the building (Morenikeji et al., 2015). Sandcrete blocks and bricks are regarded as masonry material produced from a composite of sand, cement and water. They are majorly utilized as walling materials in building of houses and for other infrastructural purposes. Sand occurs naturally in form of granular material containing fine pieces of rock and minerals elements derived from the persistent River deposits. Massive utilization of sand in the production of building blocks and concretes is causing acute shortage of sand in many places. Many people are facing challenges in the supply of sand to meet the increasing need of infrastructural development because the cost and use of sand as fine aggregate in block production is becoming very high. Consequently, there is need for integrated and economic management of sawdust in Nigeria as a replacement for sand in building in block and concrete production (Ogunwusi, 2014). Sholanke et al. (2015) reported the utilization of rice husk and rice husk ash as a partial replacement material or stabilizing agent in building works. Other studies have shown some properties of agricultural such as husk ash, palm oil fuel ash, as supplement to ordinary Portland cement concrete (Sata et al., 2004; Chandra et al., 2019).

The soaring and ever growing cost of component materials of sandcrete blocks has led to the non-realization of sufficient accommodation for both city and rural dwellers. Consequently, accessibility of substitutes to these construction materials is extremely needed for both short and long terms as catalyst for socio-economic development of our society. Particularly, cheaper raw materials that can supplement cement in the short run will be of greatly desirable.

There is no available information on the use of sawdust from Khaya senegalensis (Desr.) A. Juss. and Anogeissus leiocarpus (DC.) Guill. \& Perr. in Benue State in block making. Therefore, this study was aimed at producing hollow 
blocks from sawdust of Khaya senegalensis and Anogeissus leiocarpus commonly utilized in Makurdi as partial replacement for sand so as to recycle sawdust for the profitable resource which is currently causing the environmental problem in the metropolis.

\section{MATERIALS AND METHODS}

\section{Study area}

The experiment was carried out at the Multipurpose Laboratory of the Department of Civil Engineering, Federal University of Agriculture Makurdi (FUAM), Benue State. It lies between Latitude $7^{\circ} 38^{\prime}$ to $7^{\circ} 52^{\prime}$ North and Longitude $8^{\circ} 20^{\prime}$ to $8^{\circ} 38^{\prime}$ East in the middle belt region of Nigeria. The study area is Southern Guinea Savannah with two distinct dry and wet seasons. The climate of the place is tropical sub-humid climate with high temperatures; high humidity; average maximum and minimum daily temperature of $35^{\circ} \mathrm{C}$ and $21^{\circ} \mathrm{C}$ in wet season and $37^{\circ} \mathrm{C}$ and $16^{\circ} \mathrm{C}$ in dry season respectively. The mean annual rainfall value is $1200 \mathrm{~mm}$ to $1500 \mathrm{~mm}$. The vegetation of the area has been described as Northern Guinea savannah (PPM, 1989).

\section{Collection of materials}

Materials used for this study include were Ordinary Portland Cement obtained from the cement shop at Northbank, Makurdi. Sawdust of Khaya senegalensis and Anogeissus leiocarpus were obtained from Timber Sheds along New Bridge Wurukum, Makurdi. The sawdust was sieved and treated by boiling at $100^{\circ} \mathrm{C}$ to eliminate or reduce the retarding effect of the extractable substances in sawdust on setting and hardening bricks. The sawdust was sun dried under room temperature after boiling. River sand was collected from River Benue in Makurdi and sieved to ensure is free from dirt and particles. Portable water from FUAM water works was used.

\section{Experimental procedure}

Mortal was prepared according to ASTM C652-13 (2013), using mix ratio of 1:6 (cement to sand). River sand was replaced with sawdust at various replacement levels of $0 \%, 2 \%, 4 \%, 6 \%$ and $8 \%$ respectively, as shown in table 1 .

Table 1. Weight and percentage replacement level of sand and sawdust.

\begin{tabular}{|c|c|c|c|c|c|c|c|c|}
\hline \multicolumn{2}{|c|}{ Replacement Level (Kg) } & \multirow{2}{*}{$\begin{array}{l}\text { Cement to } \\
\text { sand ratio }\end{array}$} & \multirow{2}{*}{$\begin{array}{r}\text { Sand } \\
(\mathrm{kg})\end{array}$} & \multirow{2}{*}{$\begin{array}{r}\text { Sawdust } \\
(\mathrm{Kg})\end{array}$} & \multicolumn{3}{|c|}{ Mixture } & \multirow{2}{*}{$\begin{array}{r}\text { Water / } \\
\text { Binder Ratio }\end{array}$} \\
\hline Sand $(\%)$ & Sawdust (\%) & & & & Sand (kg) & Cement (kg) & Sawdust (kg) & \\
\hline 100 & 0 & 1.6 & 160 & 0 & 160 & 20 & 0 & 0.64 \\
\hline 98 & 2 & 1.6 & 158 & 2 & 158 & 20 & 2 & 0.86 \\
\hline 96 & 4 & 1.6 & 156 & 4 & 156 & 20 & 4 & 1.01 \\
\hline 94 & 6 & 1.6 & 154 & 6 & 154 & 20 & 6 & 1.23 \\
\hline 92 & 4 & 1.6 & 152 & 8 & 152 & 20 & 8 & 1.42 \\
\hline
\end{tabular}

\section{Production of sawdust sandcrete block}

Cement, sand and sawdust at various levels of replacement were mixed with required quantity of water. The constituents were mixed thoroughly to obtain a uniform mixture with water added randomly as deem fit during the mixing process. Specific water to cement ratios were used in the mixture of mortar according to Samuel (2014).

The composite was introduced into the block moulding machine. The blocks were produced by vibrating its freshly mixed content in the moulding machine with single $6 "(450 \mathrm{~mm} \times 225 \mathrm{~mm} \times 150 \mathrm{~mm})$ mould and vibrated with 5.0 KVA power machine for adequate compaction according to Raheem (2006). The blocks on wooden pallets were removed from the block moulding machine and placed on the ground for curing. Water was sprinkled on the blocks at least twice a day for proper curing for 28 days. Strength property, Water Absorption properties and Bulk Density were calculated from each hollow sawdust blocks within 28 days according (Adebakin et al., 2012; Thanikasalapradeep et al., 2014).

\section{Laboratory test}

Five samples of hollow blocks from each mixture were used for laboratory test (compressive strength, Density and water absorption) respectively. Compressive Strength and Water Absorption were tested using the sample bricks produced from the sawdust of Khaya senegalensis and Anogeissus leiocarpus.

\section{Percentage of water absorption test}

The water absorption capacity was determined by using the water absorption test according to Indian Standard code of practice (ISCP, 1992) and Thanikasalapradeep et al. (2014). Five block samples from each of the replacement level were weighed and their individual weighed noted as $\mathbf{M}_{1}$. These sample bricks were immersed in water for 24 hours. After 24 hours the specimens were removed from water and weighed to be determined their weight $\mathbf{M}_{2}$. Percentage Water Absorption was determined as: 
$\%$ Water Absorption $(\%)=\frac{M_{2}-M_{1}}{M_{1}} \times 100$ Eqn. i

Where, $M_{1}=$ Dried weight of bricks before soaking; $M_{2}=$ weight of bricks after soaking.

\section{Compressive strength test}

Compressive strength test on sampled hollow blocks was determined as the maximum load that the block could withstand by using the compressive strength test as per Indian Standard code of practice (ISCP, 1992). The test was carried out using the compression testing machine of maximum of 300 tones capacity. The test was progressed with a constant rate of loading $50 \mathrm{~N} / \mathrm{s}$. The surface of the block was filled with mortar and the level of bed surface was also ensured before testing. The load at which the block failed in $(\mathrm{N})$ was noted and the maximum compressive strength of individual brick was evaluated by the equation (ii) below.

$$
\text { Compressive Strength } \left.=\frac{\text { Maximum load at failure }}{\text { Contact Area }} \quad \text { in } \mathrm{N} \mathrm{mm}^{-2}\right) \ldots \ldots . \text { Eqn. ii }
$$

\section{Bulk density test}

Bulk density was carried out by dividing the weight of block unit by its dimensional volume. Mathematically expressed as:

$$
\text { Bulk Density }=\frac{\text { Weight of block }(\mathrm{kg})}{\text { dimensional volume of } \operatorname{block}\left(\mathrm{m}^{3}\right)} \ldots \ldots \ldots \ldots \ldots \ldots \ldots . . \ldots \text { Eqn. iii }
$$

\section{Data analysis}

Data collected for this study was analyzed using a simple descriptive analysis while one-way Analysis of Variance (ANOVA). Follow up test was carried out using Duncan Multiple Range Test (DMRT) where significant differences exist.

\section{RESULTS}

\section{Bulk density}

Result of bulk density of hollow blocks produced in this study is presented in table 2. The result for Annogeisus leiocarpus sawdust replacement level shows that, $100 \%$ sand and $0 \%$ sawdust replacement level had the highest $\left(1,492.00 \mathrm{~kg} \mathrm{~m}^{-3}\right)$ bulk density. This was followed by $98 \%$ sand and $2 \%$ sawdust replacement with mean density $1,329.00 \mathrm{~kg} \mathrm{~m}^{-3}, 96 \%$ sand and $4 \%$ with mean bulk density of $1,250.40 \mathrm{~kg} \mathrm{~m}^{-3}, 94 \%$ sand and $6 \%$ sawdust replacement of $1179.20 \mathrm{~kg} \mathrm{~m}^{-3}$, and $92 \%$ sand and $8 \%$ sawdust replacement with mean density of $1,111.40 \mathrm{~kg} \mathrm{~m}^{-3}$.

Similarly, for Khaya senegalensis sawdust, result reveals that $100 \%$ sand and $0 \%$ sawdust replacement level had the highest mean density of $1,506.00 \mathrm{~kg} \mathrm{~m}^{-3}$. Others include, $98 \%$ sand and $2 \%$ sawdust replacement with mean density of $1,323.00 \mathrm{~kg} \mathrm{~m}^{-3}, 96 \%$ sand and $4 \%$ sawdust replacement with mean density of $1,259.00 \mathrm{~kg} \mathrm{~m}^{-3}, 94 \%$ sand and $6 \%$ sawdust replacement having mean density of $1,191.00 \mathrm{~kg} \mathrm{~m}^{-3}, 92 \%$ sand and $8 \%$ sawdust replacement with mean density of $1,126.00 \mathrm{~kg} \mathrm{~m}^{-3}$. Bulk density was significantly different among sawdust replacement levels at $\mathrm{p} \leq 0.05$.

Table 2. Bulk Density of hollow blocks produced from sawdust of Khaya senegalensis (Desr.)

\begin{tabular}{|c|c|c|c|}
\hline \multirow{2}{*}{$\begin{array}{l}\text { Replacement Level } \\
(\%)\end{array}$} & \multirow[t]{2}{*}{$\mathbf{N}$} & \multicolumn{2}{|c|}{ Bulk Density $\left(\mathrm{kg} \mathrm{m}^{-3}\right)($ Mean \pm SDV $)$} \\
\hline & & Annogeisus leiocarpus & Khaya senegalensis \\
\hline 0 & 5 & $1,506.80 \pm 38.23^{\mathrm{e}}$ & $1,506.80 \pm 38.23^{\mathrm{e}}$ \\
\hline 2 & 5 & $1,329.00 \pm 42.54^{\mathrm{d}}$ & $1,323.00 \pm 46.92^{\mathrm{d}}$ \\
\hline 4 & 5 & $1,250.40 \pm 14.22^{\mathrm{c}}$ & $1,259.00 \pm 17.38^{\mathrm{c}}$ \\
\hline 6 & 5 & $1,179.20 \pm 6.22^{\mathrm{b}}$ & $1,191.00 \pm 12.02^{\mathrm{b}}$ \\
\hline 8 & 5 & $1,111.40 \pm 7.50^{\mathrm{a}}$ & $1,126.00 \pm 11.71^{\mathrm{a}}$ \\
\hline
\end{tabular}

A. Juss. and Anogeissus leiocarpus (DC.) Guill. \& Perr. as partial replacement for sand.

\section{Water absorption}

Table 3. Percentage (\%) Water absorption of Hollow Blocks Produced from Sawdust of Khaya senegalensis (Desr.) A. Juss. and Anogeissus leiocarpus (DC.) Guill. \& Perr. as a partial replacement for sand.

\begin{tabular}{llrr}
\hline $\begin{array}{l}\text { Replacement Level } \\
(\%)\end{array}$ & $\mathbf{N}$ & \multicolumn{2}{c}{ Water Absorption (\%) (Mean \pm SDV) } \\
\cline { 3 - 4 } & & Annogeisus leiocarpus & Khaya senegalensis \\
\hline 0 & 5 & $9.54 \pm 0.82^{\mathrm{a}}$ & $9.35 \pm 0.61^{\mathrm{a}}$ \\
2 & 5 & $11.93 \pm 2.43^{\mathrm{bc}}$ & $11.34 \pm 0.99^{\mathrm{b}}$ \\
4 & 5 & $11.13 \pm 0.74^{\mathrm{ab}}$ & $11.41 \pm 0.55^{\mathrm{b}}$ \\
6 & 5 & $12.31 \pm 0.30^{\mathrm{bc}}$ & $12.69 \pm 0.35^{\mathrm{c}}$ \\
8 & 5 & $13.07 \pm 0.58^{\mathrm{c}}$ & $13.05 \pm 0.65^{\mathrm{c}}$ \\
\hline
\end{tabular}

The result of the percentage water absorption of hollow blocks produced from sawdust of this work is shown in table 3. Mean water absorption test reveals that the higher the sawdust replacements the higher the percentage of water absorption. Mean water percentage absorption was highest (13.07\% and 13.05\%) in 92\% and 8\% sawdust replacement 
level in Annogeisus leiocarpus and Khaya senegalensis respectively. There was no much difference in mean percentage water absorption between Annogeisus leiocarpus and Khaya senegalensis sawdust replacement levels. There was no significance in mean water absorption among sawdust replacement levels.

\section{Compressive strength}

The result of the compressive strength of hollow blocks of this work is presented in table 4 below. Mean compressive strength of $100 \%$ sand and $0 \%$ sawdust replacement for both A. leiocarpus and K. senegalensis was (3.58 $\mathrm{N} \mathrm{nm}^{-2}$ ). However, as the rate of sawdust replacement levels increased, there was a corresponding decrease in the compressive strengths of hollow blocks from both wood species. The highest $\left(3.32 \mathrm{~N} \mathrm{~mm}^{-2}\right.$ and $\left.3.42 \mathrm{~N} \mathrm{~mm}^{-2}\right)$ compressive strength was recorded for $2 \%$ sawdust replacement for sand for and least $\left(1.81 \mathrm{~N} \mathrm{~mm}^{-2}\right.$ and $\left.1.85 \mathrm{~N} \mathrm{~mm}^{-2}\right)$ for $8 \%$ sawdust replacement for sand for both A. leiocarpus and K. senegalensis respectively. However, compressive strength of hollow blocks produced was higher in blocks produced from K. senegalensis than A. leiocarpus for each replacement levels. There was significant difference in compressive strength of hollow blocks produced from among sawdust replacement levels for sand at $\mathrm{p} \leq 0.05$.

Table 4. Compressive strength Test of Hollow Blocks Produced from Sawdust of Khaya senegalensis (Desr.) A. Juss. and Anogeissus leiocarpus (DC.) Guill. \& Perr. as a partial replacement for sand.

\begin{tabular}{|c|c|c|c|c|c|c|}
\hline \multirow[t]{2}{*}{$\begin{array}{l}\text { Replacement } \\
\text { Level (\%) }\end{array}$} & \multirow[t]{2}{*}{$\begin{array}{l}\text { Block } \\
\text { No }\end{array}$} & \multirow{2}{*}{$\begin{array}{r}\text { Net Area } \\
\text { of Block } \\
\left(\mathrm{mm}^{2}\right)\end{array}$} & \multicolumn{2}{|c|}{$\begin{array}{c}\text { Crushing Load }(\mathrm{KN}) \\
(\text { Mean } \pm \text { SDV })\end{array}$} & \multicolumn{2}{|c|}{$\begin{array}{l}\text { Compressive Strength of the } \\
\text { Block }\left(\mathrm{N} \mathrm{mm}^{-2}\right)(\text { Mean } \pm \text { SDV })\end{array}$} \\
\hline & & & $\begin{array}{r}\text { Annogeisus } \\
\text { leiocarpus }\end{array}$ & $\begin{array}{r}\text { Khaya } \\
\text { senegalensis }\end{array}$ & $\begin{array}{r}\text { Annogeisus } \\
\text { leiocarpus }\end{array}$ & $\begin{array}{r}\text { Khaya } \\
\text { senegalensis }\end{array}$ \\
\hline \multirow{5}{*}{$0 \%$} & 1 & 36900 & 130 & 134 & \multirow{5}{*}{$3.58 \pm 0.06^{\mathrm{e}}$} & \multirow{5}{*}{$3.58 \pm 0.06^{\mathrm{e}}$} \\
\hline & 2 & 36900 & 126 & 130 & & \\
\hline & 3 & 36900 & 128 & 132 & & \\
\hline & 4 & 36900 & 130 & 130 & & \\
\hline & 5 & 36900 & 128 & 134 & & \\
\hline \multirow{5}{*}{$2 \%$} & 1 & 36900 & 124 & 127 & \multirow{5}{*}{$3.32 \pm 0.06^{\mathrm{d}}$} & \multirow{5}{*}{$3.42 \pm 0.04^{\mathrm{d}}$} \\
\hline & 2 & 36900 & 120 & 126 & & \\
\hline & 3 & 36900 & 124 & 128 & & \\
\hline & 4 & 36900 & 120 & 124 & & \\
\hline & 5 & 36900 & 124 & 126 & & \\
\hline \multirow{5}{*}{$4 \%$} & 1 & 36900 & 116 & 120 & \multirow{5}{*}{$3.16 \pm 0.03^{c}$} & \multirow{5}{*}{$3.25 \pm 0.04^{\mathrm{c}}$} \\
\hline & 2 & 36900 & 116 & 118 & & \\
\hline & 3 & 36900 & 118 & 122 & & \\
\hline & 4 & 36900 & 116 & 120 & & \\
\hline & 5 & 36900 & 118 & 120 & & \\
\hline \multirow{5}{*}{$6 \%$} & 1 & 36900 & 86 & 90 & \multirow{5}{*}{$2.25 \pm 0.07^{\mathrm{b}}$} & \multirow{5}{*}{$2.36 \pm 0.06^{\mathrm{b}}$} \\
\hline & 2 & 36900 & 80 & 88 & & \\
\hline & 3 & 36900 & 84 & 86 & & \\
\hline & 4 & 36900 & 84 & 84 & & \\
\hline & 5 & 36900 & 80 & 8 & & \\
\hline \multirow{5}{*}{$8 \%$} & 1 & 36900 & 68 & 70 & \multirow{5}{*}{$1.81 \pm 0.08^{\mathrm{a}}$} & \multirow{5}{*}{$1.85 \pm 0.05^{\mathrm{a}}$} \\
\hline & 2 & 36900 & 64 & 66 & & \\
\hline & 3 & 36900 & 68 & 70 & & \\
\hline & 4 & 36900 & 70 & 68 & & \\
\hline & 5 & 36900 & 64 & 68 & & \\
\hline
\end{tabular}

\section{DISCUSSION}

Bulk density of hollow blocks produced from sawdust replacement level ranged between $1,329.00 \mathrm{~kg} \mathrm{~m}^{-3}$ to $1,111.400 \mathrm{~kg} \mathrm{~m}^{-3}$ and decreased with increase in percentage of sawdust substitution. For all cases considered, the minimum density obtained was least $\left(1,111.400 \mathrm{~kg} \mathrm{~m}^{-3}\right)$ in $8 \%$ sawdust replacement levels. This is less than the minimum value of $1,500 \mathrm{~kg} \mathrm{~m}^{-3}$ recommended for first grade sand crated blocks by Nigerian Industrial Standard 087 , (NIS, 2000) for load bearing walls. The minimum value of density obtained in the study meets the requirement of New Technology for Rural Development (NTRD, 2009) which ranges from $1,000 \mathrm{~kg} \mathrm{~m}^{-3}$ to $1,100 \mathrm{~kg} \mathrm{~m}^{-3}$ for non-load bearing walls. The mean density values of hollow blocks obtained are lower than those obtained by Raheem (2006) which ranged from $2,073.5 \mathrm{~kg} \mathrm{~m}^{-3}$ to $2,166.3 \mathrm{~kg} \mathrm{~m}^{-3}$. This may be due to differences in the physical properties of the sand and wood species used and the substitution levels of sawdust in the production control. However, these values are also less than the above minimum value of $1,500 \mathrm{~kg} \mathrm{~m}^{-3}$ recommended for first grade hollow blocks by Nigerian Industrial Standard 087, (NIS, 2000). There was no significant difference in bulk density among the means of all the replacement levels at $\mathrm{p} \leq 0.05$. 
Water absorption of test blocks increased as the percentage replacement of sawdust for sand increased. Hollow blocks with $8 \%$ sawdust replacement were the most porous with the absorption rate of $13.07 \%$ for Annogeisus leiocarpus and $13.05 \%$ for Khaya senegalensis. The water absorption rate is less than $18.2 \%$ obtained by Ekhuemelo et al. (2016). The water absorption rate is also less than $16.95 \%$ obtained by Anosike et al. (2011), but higher than the acceptable value of $12 \%$ according to British Standards Institution (2005). The reason for increase in water absorption may be as a result of trapped air bubbles due to porosity of the sawdust. From the water absorption test result, there are significant differences among the means of all the replacement levels.

The maximum mean compressive strength $3.58 \mathrm{~N} \mathrm{~mm}^{-2}$ of hollow blocks produced from $100 \%$ sand and $0 \%$ sawdust replacement level is above the minimum standard for load bearing walls of $2.0 \mathrm{~N} \mathrm{~mm}^{-2}$ according to the National Building Code (NBC, 2006), and $2.75 \mathrm{~N} \mathrm{~mm}^{-2}$ according to Ghana Building code (GBC, 1989). However, the compressive strength values met the $3.5 \mathrm{~N} \mathrm{~mm}^{-2}$ British Standards. Mean compressive strength of hollow blocks produced with $2 \%$ and $4 \%$ sawdust replacement for sand are above the minimum requirement of $1.4 \mathrm{~N} \mathrm{~mm}^{-2}$ according to Ghana Building Code (GBC, 1989) for non-load bearing walls. Mean comprehensive strength of hollow blocks produced from $2 \%, 4 \%, 6 \%$ and $8 \%$ sawdust replacement levels are above $1.5 \mathrm{~N} \mathrm{~mm}^{-2}$ obtained by Ekhuemelo et al. (2016). Test result indicates that the compressive strength decreased with increase in sawdust content. This finding agrees to Adebakin et al. (2012) report on utilization of sawdust as mixture in the production of cheaper and lightweight hollow blocks.

\section{CONCLUSION}

It was observed that the density of hollow blocks decreased as the percentage replacement levels of sand with sawdust increased. Percentage of water absorption increased as the percentage replacement of sand with sawdust increases. While compressive strength of hollow blocks also decreased as the percentage replacement levels of sawdust increased. The best sawdust replacement level was $2 \%$ for both Annogeissus leiocarpus and Khaya senegalensis replacement. Therefore, $2 \%$ sawdust replacement level in blocks production as obtained in this study is recommended for non-load bearing walls. To achieve a better result in the use of sawdust in block production, the percentage replacement of sand by weight of sawdust should not be more than $4 \%$ as in this study.

\section{RECOMMENDATIONS}

i. 4\% sawdust replacement level in block production should be encouraged in the production of hollow blocks to reduce cost as obtained in the study.

ii. Further research should be carried out to evaluate sawdust of different species for hollow blocks production.

\section{ACKNOWLEDGEMENTS}

The authors wish to acknowledge the assistance of Technical staff in the Department of Civil Engineering, Federal University of Agriculture Makurdi, for kind supports and guidance.

\section{REFERENCES}

Adebakin I.H. (2012). Uses of sawdust as admixture in production of low-cost and light-weight hollow sandcrete blocks. American Journal of Scientific and Industrial Research, 3(6): 458-463.

Anosike M.N. (2011). Parameters for Good Site Concrete Production Management Practicein Nigeria, (Ph. D. Thesis). Covenant University, Ota, Nigeria.

ASTM C652-13 (2013). Standard Specification for Hollow Bricks (Hollow Masonry Units made from clay or shale); Astm.org.

Chandra P.S., Mbewe P., Kong S. \& Šavija B. (2019). Agricultural Solid Waste as Source of Supplementary Cementitious Materials in Developing Countries. Materials, 12(7): 1112.

Dosunmu O.O. \& Ajayi A.B. (2002). Problems and management of sawmill waste in Lagos. Proceedings of International Symposium on Environmental Pollution Control and Waste Management 7-10 January 2002, Tunis (EPCOWM'2002), pp. 271278.

Ekhuemelo D.O., Ademu O. \& Tembe E.T. (2016). Physical and strength properties of bricks produced from Portland cement and saw dust of Danielia oliverii wood. PRO LIGNO. Scientific Journal in the field of wood engineering, 12(4): 53-60.

PPM (1989). Physical Planning Manual (PPM). Geographical location of Federal University of Agriculture, Makurdi.

GBC (1989). Ghana Building Code. Ministry of Works and Housing: Kumasi, Ghana.

ASCP (1992). Methods of tests of Burnt clay building bricks. Indian Standard code of practice, [IS 3495 (Part 1-4)].

Morenikeji G., Umaru E.T., Liman S.H. \& Ajagbe M.A. (2015). Application of Remote Sensing and Geographic Information System in Monitoring the Dynamics of Land use in Minna, Niger State, Nigeria. International Journal of Academic Research in Business and Social Sciences, 5(6): 320-337.

NBC (2006). Building Regulations, National Building Code. LexisNexis Butterworths, Ohio.

NTRD (2009). New Technology Rural Development. 
NIS (2000). Nigerian Industrial Standard: Standard for Sandcrete Blocks. Standards Organisation of Nigeria, Lagos, Nigeria.

Ogunbode E.B., Fabunmi F.O., Ibrahim S.M., Jimoh I.O. \& Idowu O.O. (2013). Management of Sawmill Wastes in Nigeria: Case Study of Minna, Niger State. Greener Journal of Science, Engineering and Technology Research, 3(2): 34-41.

Ogunwusi A.A. (2014). Wood Waste Generation in the Forest Industry in Nigeria and Prospects for its Industrial Utilization. Civil and Environmental Research, 6(9): 62-69.

Raheem A.A. (2006). Comparism of the Quality of Sandcrete Blocks Produced by LAUTECH Block Industry with others within Ogbomoso Township. Science Focus, 11(1): 103-108.

Samuel S.O. (2014). An assessment of the compressive strength of solid sandcrete blocks-in Idiroko area of Nigeria. Research Journal in Engineering and Applied Sciences, 3(1) 38-42.

Sata V., Jaturapitakkul C. \& Kiattikomol K. (2004). Utilization of palm oil fuel ash in high-strength concrete. Journal of Materials in Civil Engineering, 16: 623-628.

Sholanke A.B., Fagbenle O.I., Aderonmu A.P. \& Ajagbe M.A. (2015). Sandcrete Block and Brick Production in Nigeria - Prospects And Challenges. International Journal of Environmental Research, 1(4): 1-17.

Thanikasalapradeep N., Selvakumar V., Sinthiya R., Srinivas V. \& Premavathi N. (2014). Experimental Approach to Investigate the Behaviour of Brick Masonry for Different Mortar Ratios. In: International Conference on Advances in Engineering and Technology (ICAET, 2014) March 29-30, 2014, Singapore. 